\title{
The Limits of Liberalism in Argentine Provinces 1890-1940: An Analysis of Provincial Expenditures
}

\author{
Jim Levy and Peter Ross, University of New South Wales
}

\section{Introduction}

The last quarter of the nineteenth century witnessed a decisive turn in the economic and political trajectory of Argentina. Economically, the nation experienced considerable growth based on the export of agro pastoral products, the expansion of infrastructure particularly railways and ports, and the importation of large numbers of workers, particularly from Italy and Spain, but also from many other European states, and from neighbouring countries (Devoto 2007; Benencia 2007). The principles that underlay this expansion were liberal. Argentina exported primary products (grains and meat) with some value adding in the case of meat, and imported manufactures. Import substitution industrialisation did occur, generally in times of international crises (the 1890s, World War 1, and the 1930s) but was not based on government policy in the period under consideration, though the fact that national revenues were dependent on custom taxes did encourage some manufacturing growth (Rapoport 2006: 172). Laissez faire, however, remained the hegemonic economic doctrine, and not just of the large landowners, international merchants and financiers, but also of many of the groups that represented the interests of the working class including the Socialist Party. The latter argued that laissez faire lowered the costs of many of the products that working families had to buy (Solberg 1973: 265).

Until 1916 political power was exercised by a liberal oligarchy. The 1853 Argentine constitution recognised the right to universal male suffrage but the electoral system was 
characterised by clientelism and the corruption of suffrage by means of violence, fraud and vote buying. Eduardo Posada-Carbó (2000) has put these practices into the contemporary, international context of both Latin America and other parts of the globe, including Europe and North America, while other researchers (Alonso 1993; Canton \& Jorrat 1999; Negretto \& Aguilar-Rivera 2000), via close studies of particular elections, have revealed that fraud and other sharp practices were not always determinant in electoral victories for the period. A section of the oligarchy did appeal to, and receive the support of, urban and rural citizens who were not members of the landed, commercial and financial elite. A wide range of civil society did participate in public sphere institutions, including political processes (Sabato 2001). Divisions within the ruling class fomented political discourse and political activity.

The system was, however, exclusionary. Women, with notable exceptions, were largely left out of the political process, as were many immigrants who were not encouraged to become citizens. The 1912 electoral reform, legislating obligatory and secret voting for male citizens, resulted in a wider franchise and less fraudulent elections, although throughout the Radical Party years of government from 1916 to 1930 clientelism still played a role in securing votes. However, as Joel Horowitz (1999) argues, distribution of favours is not a sufficient explanation of Radical Party electoral success. The military overthrow of the Yrigoyen government in 1930 ushered in a decade of fraudulent electoral practices under liberal conservative governments, though some space remained for participation in the managed elections.

The reversal of the extension of political rights of the populace in 1930 indicates the failure of the economic elites to construct the sort of hegemonic liberal state that they desired. Similarly, their rejection of Peronism in the post Second World War period, even though it extended the suffrage to include women in 1947 and was based on electoral processes, reveals that their avowed aim of building the Argentine state on democratic foundations took second place to their economic objectives. For the most part, the liberal elites failed to realise that a fully functioning democracy requires more than political rights. Citizens need to be integrated into the state by means of social policies. The elites were aware of the social difficulties of the lower classes, particularly in the burgeoning cities that resulted from the economic boom. They were also concerned about the possibilities of revolt, rebellion and revolution. But they framed 
these concerns as a 'social problem' and addressed them from an elitist and positivist ideology that flowed from concepts of race, social Darwinism, biological determinism and disease (Zimmermann 1992). Even the Socialist Party, dominated by professionals, especially doctors, distrusted the masses. Socialist Party leaders were as paternalist as the liberal elite (Adelman 1992).

For the most part, liberalism in Argentina left social welfare outside the sphere of the state. Charity organisations, many of which were connected with the Catholic Church, provided, with state financial support, most of the health and social assistance available to the poorest sections of the community. Mutual aid organisations were also important though these, for the most part, lacked the resources to care for their voluntary members in times of severe general crises. The Socialist Party and socially conscious sections of the Catholic Church (Recalde 1985) did have some success in securing social reforms to protect workers and their families, and in the cities, particularly the Federal Capital, limited public health facilities were instituted in the face of serious outbreaks of infectious diseases. However, by the 1940s the lower socio-economic groups still lacked adequate social protection, and when they did receive it, it was generally not as a right but as a gift from the well off (Mallimaci 2007: 98-103). Only about 10 percent of the waged population were members of pension funds at the end of the period (Ross 1988: $65 a)$.

The paucity of social welfare provisions highlights the limits of the liberal state as built by the political and economic elites prior to the 1940s. It is the purpose of this paper to underscore this contention by a close analysis of Argentine provincial government expenditure between 1890 and 1940. This is part of a wider study of provincial revenue raising and expenditure from the late nineteenth century to 1965. For this paper we have selected the seven most important of the 14 Argentine provinces of the period, namely Buenos Aires, Córdoba, Corrientes, Entre Ríos, Mendoza, Santa Fe and Tucumán. Together they represented over 80 percent of the Argentine provincial population and provincial production, and can be taken as indicative of the general policy trajectories of the provinces as a whole. It must be noted that information on government spending supplied by provincial authorities is not transparent. Actual expenditure is often very much at odds with the official budgets. Indeed, the latter are frequently repeated year after year. Moreover, budgets are amended during financial years by ministerial decree 
and by the legislature, and often the funding of these special laws and decrees is not clarified. The result is that governmental floating debt increases. Governments secured both internal and foreign loans to cover deficits and also to finance public works. Rarely did provincial governments provide a clear statement with regard to their finances and expenditure.

\section{Overview 1890-1940}

By 1890 the basic structure of provincial governments had been established. As Tables 1,2 and 3 reveal, the structure of government expenditure did not change radically during the period under consideration, though the proportion of funds dedicated to particular parts of that structure do vary. The principal areas funded by government remained law and order, and education. The servicing of debt was also a considerable expense for some of the provinces, and generally increased due to more spending on public works. Expenditure on welfare and health was rarely significant, though there is an increase in such expenditure in some provinces in the late 1930s. Differences in proportions of expenditure for different categories within and between provinces will be addressed further on in the paper.

\begin{tabular}{|l|l|l|l|l|l|l|l|}
\hline Prov. & Gov. & Law/Order & Ed. & Debt & $\begin{array}{l}\text { Pub. } \\
\text { Works }\end{array}$ & Welfare & Health \\
\hline Bs. As. & 6.6 & 26.8 & 25.5 & 5.1 & 3.8 & 5.0 & 1.3 \\
\hline Cord. & 8.0 & 45.9 & 18.2 & 2.8 & 2.1 & 3.3 & 0.3 \\
\hline Corr. & 10.6 & 43.8 & 23.2 & 4.9 & 1.6 & 0.7 & 0.0 \\
\hline E.R. & 4.8 & 26.7 & 11.7 & 37.4 & 4.0 & 2.8 & 1.3 \\
\hline Mend. & 0.0 & 45.7 & 8.4 & 8.2 & 4.5 & 7.4 & 0.0 \\
\hline S. F. & 6.8 & 54.1 & 12.9 & 4.1 & 0.3 & 2.9 & 0.3 \\
\hline Tuc. & 0.0 & 26.0 & 12.2 & 40.4 & 4.1 & 2.5 & 0.9 \\
\hline
\end{tabular}

Table 1: Provincial Budgets 1895: Proportion of Expenditure by Major Categories ${ }^{1}$

\begin{tabular}{|l|l|l|l|l|l|l|l|}
\hline Prov. & Gov. & Law/Order & Ed. & Debt & $\begin{array}{l}\text { Pub. } \\
\text { Works }\end{array}$ & Welfare & Health \\
\hline Bs. As. & 5.6 & 21.3 & 22.0 & 25.7 & 2.4 & 2.6 & 1.7 \\
\hline Cord. & 5.5 & 45.3 & 18.6 & 6.5 & 2.5 & 4.4 & 0.4 \\
\hline Corr. & 8.2 & 44.6 & 22.3 & 4.2 & 3.5 & 0.7 & 0.3 \\
\hline E.R. & 4.0 & 30.3 & 20.3 & 9.3 & 7.8 & 1.1 & 0.6 \\
\hline Mend. & 0.0 & 37.9 & 5.5 & 24.2 & 3.9 & 1.3 & 6.9 \\
\hline S. F. & 4.6 & 36.2 & 11.8 & 22.7 & 0.3 & 2.3 & 0.4 \\
\hline Tuc. & 0.0 & 36.5 & 18.8 & 17.0 & 5.7 & 4.0 & 1.4 \\
\hline
\end{tabular}

Table 2: Provincial Budgets 1910: Proportion of Expenditure by Major Categories ${ }^{2}$

\footnotetext{
${ }^{1}$ Source: Dirección General de Estadística (1896: 90-106). In these and subsequent tables: Law/Order includes Justice, Police, and Jails; Welfare includes charity, scholarships, pensions, and subsidies; Health includes specific funding for health authorities, sanitation and hospitals.

${ }^{2}$ Source: Dirección General de Estadística (1911: 204-23).
} 


\begin{tabular}{|l|l|l|l|l|l|l|l|}
\hline Prov. & Gov. & Law/Order & Ed. & Debt & $\begin{array}{l}\text { Pub. } \\
\text { Works }\end{array}$ & Welfare & Health \\
\hline Bs. As. & 4.6 & 16.4 & 19.7 & 32.7 & 6.4 & 4.6 & 7.3 \\
\hline Cord. & 11.3 & 30.5 & 17.5 & 22.5 & 14.2 & 3.1 & 4.6 \\
\hline Corr. & 5.9 & 36.6 & 18.3 & 13.7 & 4.8 & 3.4 & 1.2 \\
\hline E.R. & 3.3 & 27.9 & 24.7 & 9.8 & 10.8 & 8.3 & 0.4 \\
\hline Mend. & 13.4 & 19.1 & 17.0 & 14.0 & 11.0 & 21.8 & $\begin{array}{l}\text { in } \\
\text { welfare }\end{array}$ \\
\hline S. F. & 1.3 & 32.3 & 27.4 & 16.4 & 8.8 & 1.8 & 3.1 \\
\hline Tuc. & 0.0 & 36.5 & 18.8 & 17.0 & 5.7 & 4.0 & 1.4 \\
\hline
\end{tabular}

Table 3: Provincial Budgets about 1935: Proportion of Expenditure by Major Categories. ${ }^{3}$

\section{Police, Justice and Jails}

The police and the justice ministry were important not just for the prevention of crime, and the apprehension and prosecution of criminals, but also to repress political forces opposed to the government. The Radicals, in their desire for electoral reform (universal male suffrage), mounted a number of revolts prior to the electoral reform of 1912, but governments could also be threatened by members of their own oligarchic class.

Moreover, police repressed strikes and other actions by social groups seeking to improve their situation. A further very important function of the police was political. In the absence of strong national political parties, the police could be used to organise voters throughout the province and deliver victory to political leaders who enjoyed their support. As an anonymous writer of a history of the police in Entre Ríos expressed it in 1947, the department heads of the police were the 'natural agents' of the executive (Anonymous 1947).

\begin{tabular}{|c|c|c|c|}
\hline Prov & $\mathbf{1 8 9 5}$ & $\mathbf{1 9 1 0}$ & $\mathbf{1 9 3 0 s}$ \\
\hline Bs. As. & 26.8 & 21.3 & 16.4 \\
\hline Cord. & 45.9 & 45.3 & 30.5 \\
\hline Corr. & 43.8 & 44.6 & 36.6 \\
\hline E.R. & 26.7 & 30.3 & 27.9 \\
\hline Mend. & 45.7 & 37.9 & 19.1 \\
\hline S. F. & 54.1 & 36.2 & 32.3 \\
\hline Tuc. & 26.0 & 36.5 & 36.5 \\
\hline
\end{tabular}

Table 4: Law/Order as a Proportion of Provincial Budgets: Selected Years.

As table 4 reveals, most provinces were devoting a smaller proportion of their budgets to the forces of law and order in the latter part of the 1930s than they had to 1910. The

\footnotetext{
${ }^{3}$ Sources: For Buenos Aires 1935: Ministerio de Gobierno de la Provincia de Buenos Aires (1944: 51819. For Córdoba 1935: Ministerio de Hacienda de la Provincia de Córdoba (1936: 120-21). For Corrientes 1937: Contaduría General (Corrientes) (1938: 51-57). For Entre Ríos 1932: Ministerio de Gobierno y Obras Públicas de la Provincia de Entre Ríos (1932: anexo, n.p.). For Mendoza 1941: Gobierno deMendoza (1954: 148). For Santa Fe 1935: Contaduría General de la Provincia de Santa Fe (1936: 1011). For Tucumán 1935: 1938, Anuario de Estadístico (1938: 166).
} 
reduction is most notable in the case of the Province of Buenos Aires although its proportions in 1895 and 1910 were already relatively low. Mendoza is also noteworthy because of the marked decline from 1910 to the 1930s. The other provinces, however, were still spending from 27 to 37 percent of their budgets on police, justice and jails in the 1930s. No detailed study of policing has yet been produced for Argentina. However, in the context of the theme of the limits of liberalism proposed in this paper, the following points may provide some explanation of the figures in Table 4.

In a social and economic system that provided little security for poorer people, crime was likely to be more common. Lyman L. Johnson and Leandro Wolfson (1989) argue that violent crime was more prevalent in the cities of Buenos Aires, Santa Fe and Tucumán than in similar cities in other parts of the world because the sort of development in Argentina, with its high intake of young male immigrants, created a group of unskilled workers with little job security and a limited social network. Similarly, the lack of protection of workers, rural and urban, and of land renters, resulted in considerable unrest, particularly in the pampean regions between 1912 and 1930. Governments, whether oligarchic or Radical, almost always responded with repression rather than with reforms. (Solberg 1971). An important exception occurred in Santa Fe in May 1928 when, in the context of the electoral victory of the Radical Personalists over the Antipersonalists in both national and provincial elections, the new police chief, Ricardo Caballero, refused to repress striking workers in Rosario with the result that by the end of the year unrest had spread to other cities and to rural areas. Caballero's actions reflected the attempt by some of the provincial Radicals to forge a political alliance with labour unions and demonstrated the importance of the police as a political force. Employers objected with the classical liberal argument that strikes and organised labour represented an attack on their freedom. They gained the ear of President Yrigoyen who despatched federal troops to quell the unrest (Korzeniewicz 1993).

The necessity to control labour unrest and to organise the delivery of votes probably explains the continuing relatively high rates of expenditure on law and order in the provinces of Santa Fe, Tucumán, Córdoba, Entre Rios and Corrientes during the 1930s. The Province of Buenos Aires was the most economically developed of the provinces and perhaps therefore crime was not as prevalent as in some of the other provinces. 
Moreover, from the nineteenth century, politics was highly organised at local levels in clientelistic networks that reduced the necessity to use the police to mobilise voters. In Mendoza, the social reforms associated with the populist Radical Party Lencinas movement of the 1920s created a more inclusive society that permitted the relative reduction of spending on state repressive forces.

\section{Education}

The provision of primary education was the one great social project of the liberal oligarchy. It was seen as the means to construct a national identity that would integrate the Argentine people, including immigrants, and create social cohesion. Secondary schools and universities were envisioned as the preserve of the elite. In effect, they existed to train the leaders of the future (Tedesco and Cardini 2007: 440). Obligatory, lay, and free primary school education was legislated nationally in 1884. Responsibility for the provision of primary schools within provinces remained with the provincial governments. For the most part, these strove to provide education at this level, their leaders ascribing to the nation building objectives of the national state.

Education, as can be seen in Table 5, was therefore a major investment area of provincial governments. Some provinces, such as Entre Ríos from early in the twentieth century, constitutionally guaranteed the funding of education by means of special tax regimes that ensured that fixed proportions of land and other taxes were earmarked for this sector.

\begin{tabular}{|l|l|l|l|}
\hline Prov. & $\mathbf{1 8 9 5}$ & $\mathbf{1 9 1 0}$ & $\mathbf{1 9 3 0 s}$ \\
\hline Bs. As. & 25.5 & 22.0 & 19.7 \\
\hline Cord. & 18.2 & 18.6 & 17.5 \\
\hline Corr. & 23.2 & 22.3 & 18.3 \\
\hline E.R. & 11.7 & 20.3 & 24.7 \\
\hline Mend. & 8.4 & 5.5 & 17.0 \\
\hline S. F. & 12.9 & 11.8 & 27.4 \\
\hline Tuc. & 12.2 & 18.8 & 18.8 \\
\hline
\end{tabular}

Table 5: Education as a Proportion of Provincial Budgets: Selected Years.

Provincial revenues, however, were never sufficient to fund education adequately. The national governments aided them by means of an annual subsidy, and also commenced supplying nationally funded schools (the Láinz schools) in the provinces from 1905. As Table 6 shows, the national schools were particularly numerous as compared with provincial schools in Corrientes, and Tucumán, but were also significant in Santa Fe 
and Mendoza. This indicates that these provinces lacked the resources or the political will to provide primary level education to all their children. This was certainly true for Mendoza until the 1930s when education clearly became a major priority as compared to the previous decades.

\begin{tabular}{|l|l|l|l|}
\hline Prov. & National & Provincial & Private \\
\hline Bs. As. & 191 & 2051 & 247 \\
\hline Cord. & 295 & 709 & 122 \\
\hline Corr. & 360 & 146 & 18 \\
\hline E.R. & 152 & 520 & 97 \\
\hline Mend. & 122 & 255 & 27 \\
\hline S.F. & 419 & 644 & 200 \\
\hline Tuc. & 301 & 190 & 19 \\
\hline
\end{tabular}

Table 6: National, Provincial and Private Schools in $1929 .{ }^{4}$

Illiteracy declined considerably over the fifty year period. However, many children still did not attend school, or did not complete even four years of primary education. Moreover, in many provinces at different periods payment of teacher salaries was seriously in arrears.

\section{Public Works and Debt}

Provincial revenues alone did not permit much expenditure on public works. During the 1890s, because of the depression and the parlous nature of provincial finances, there were few public works. The major exception, as revealed in Table 7, was Mendoza which continued to invest in irrigation schemes to encourage the production of wine.

\begin{tabular}{|c|c|c|c|}
\hline Prov. & $\mathbf{1 8 9 5}$ & $\mathbf{1 9 1 0}$ & $\mathbf{1 9 3 0 s}$ \\
\hline Bs. As. & 3.8 & 2.4 & 6.4 \\
\hline Cord. & 2.1 & 2.5 & 14.2 \\
\hline Corr. & 1.6 & 3.5 & 4.8 \\
\hline E.R. & 4.0 & 7.8 & 10.8 \\
\hline Mend. & 4.5 & 3.9 & 11.0 \\
\hline S. F. & 0.3 & 0.3 & 8.8 \\
\hline Tuc. & 4.1 & 5.7 & 5.7 \\
\hline
\end{tabular}

Table 7: Public Works as a Proportion of Provincial Budgets: Selected Years.

The provinces generally relied on loans, domestic and foreign, to build schools, police stations, and other government buildings, and to construct bridges and other necessary infrastructure such as paving, canals and irrigation channels. Little money was spent on roads until the 1920s, but only after 1933 was much achieved, and that mainly due to the federal government providing funds on the basis that the provinces made a

\footnotetext{
${ }^{4}$ Source: Consejo Nacional (1929: 295-297).
} 
contribution. Not all loans were taken out, either, to fund public works. Many of the provinces overspent on their budgets and loans were secured to cover this floating debt.

The reliance on loans for public works explains the rising levels of debt servicing as a proportion of provincial expenditure. The figures in Table 8 are not all to be taken at face value since the responsibility to fund some loans was not acknowledged. During the 1890s and 1930s, some loan repayments were put into abeyance, and even in 1910 a number of the provinces were not making loan repayments to the federal government as they were required to do under the nationalization of debt agreements that had been signed in the 1890s. Entre Ríos, for example, made no repayments on its mn\$6.5 million debt to the Nation until 1938, while Córdoba and Santa Fe did not make regular payments over the period. Under the agreement reached with the national government in the 1890s, the provinces were not supposed to return to the international financial markets to secure loans. But, beginning in 1905 with the Province of Buenos Aires, all did so with the exception of Entre Ríos.

Provinces also fell into arrears in the payment of foreign and domestic loans. Buenos Aires suspended debt servicing of some loans between 1915 and 1917, and was not always up to date with repayments during the 1920s. Corrientes ceased making amortisation payments on its 1910 foreign railway loan in 1915, and stopped paying interest in 1921, while Córdoba was in arrears in paying off domestic loans between 1915 and 1929. With the onset of the 1930 depression many provinces fell behind with repayments. Santa Fe officially declared a moratorium on debt servicing in 1932.

\begin{tabular}{|l|l|l|l|}
\hline Prov. & $\mathbf{1 8 9 5}$ & $\mathbf{1 9 1 0}$ & $\mathbf{1 9 3 0 s}$ \\
\hline Bs. As. & 5.1 & 25.7 & 32.7 \\
\hline Cord. & 2.8 & 6.5 & 22.5 \\
\hline Corr. & 4.9 & 4.2 & 13.7 \\
\hline E.R. & 37.4 & 9.3 & 9.8 \\
\hline Mend. & 8.2 & 24.2 & 14.0 \\
\hline S. F. & 4.1 & 22.7 & 16.4 \\
\hline Tuc. & 40.4 & 17.0 & 17.0 \\
\hline
\end{tabular}

Table 8: Debt Service as a Proportion of Provincial Budgets: Selected Years

\section{Welfare}

For the most part welfare was left to the private sector. Provincial governments in the early period did give ex gracia pensions to individuals whose cases were advanced by 
legislators. Often these were family members of deceased parliamentarians or the families of eminent people such as destitute or reportedly destitute professionals. Over time, provincial governments instituted superannuation and pension schemes for state employees and workers. As with similar federal schemes, these funds often experienced financial difficulties because of the failure of governments to pay their contribution, to under capitalisation, to the generosity of benefits, and to the raiding of the funds by provincial governments to fund debt and public works. The only province to attempt to institute a more universal system of old age pensions was Mendoza in the 1920s. The success of this was limited.

\begin{tabular}{|l|l|l|l|l|l|l|}
\hline Year. & $\mathbf{1 8 9 5}$ & $\mathbf{1 8 9 5}$ & $\mathbf{1 9 1 0}$ & $\mathbf{1 9 1 0}$ & $\mathbf{1 9 3 0 s}$ & $\mathbf{1 9 3 0 s}$ \\
\hline Prov. & Welfare & Health & Welfare & Health & Welfare & Health \\
\hline Bs. As. & 5.0 & 1.3 & 2.6 & 1.7 & 4.6 & 7.3 \\
\hline Cord. & 3.3 & 0.3 & 4.4 & 0.4 & 3.1 & 4.6 \\
\hline Corr. & 0.7 & 0.0 & 0.7 & 0.3 & 3.4 & 1.2 \\
\hline E.R. & 2.8 & 1.3 & 1.1 & 0.6 & 8.3 & 0.4 \\
\hline Mend. & 7.4 & 0.0 & 1.3 & 6.9 & 21.8 & $\begin{array}{l}\text { in } \\
\text { welfare }\end{array}$ \\
\hline S.F. & 2.9 & 0.3 & 2.3 & 0.4 & 1.8 & 3.1 \\
\hline Tuc. & 2.5 & 0.9 & 4.0 & 1.4 & 4.0 & 1.4 \\
\hline
\end{tabular}

Table 9: Welfare and Health as Proportions of Provincial Budgets: Selected Years

Provincial governments also provided some grants to a plethora of private institutions involved in such activities as supplying milk to school children, and looking after the aged, destitute, infirm, handicapped and mentally ill. A few provinces established institutes to care for the blind and deaf. Libraries, rifle ranges and sporting and cultural clubs received some occasional funding. Provinces also maintained government libraries, museums and parks, and funded official fiestas.

\section{Health}

Spending on health amounted to a relatively small proportion of provincial government budgets, as can be seen in Table 9. For the most part these were perceived as lying within the gamut of private concerns. Most curative health facilities (hospitals for example) were run and financed by charity or religious organizations, as were asylums and homes for the aged and indigent. Provincial governments did provide some funding via grants, but this was not substantial. Some private organizations also received some grants from the federal government. In most of the provinces, municipalities controlled more of the curative health sector than did the provincial governments. 
Provincial governments did fund Health Boards (Consejos de Higiene). These consisted of a committee of eminent doctors and a few functionaries whose responsibilities ranged from policing health practitioners, overseeing the general health situation of the province, and conducting vaccination campaigns. These did not always function terribly well. The governor of Córdoba in 1917 reported that the province’s Board had met only four times in the previous eight years. It consisted of a governing committee of three, one inspector of pharmacies, one health inspector, one medical student, four medical students to carry out vaccinations, and two disinfection workers. The chemical laboratory was badly deteriorated and had no running water or functional lighting. There was no archive, no register of health professionals, and no denunciations of infectious disease outbreaks had occurred. As a result, many pharmacists operated without qualifications in establishments that had never been inspected, and many individuals practised medicine, including obstetrics, illegally (Loza 1917: 34-35).

It is only in the 1930s that provincial governments begin to assume a greater role in both preventive and curative medicine, and even then the steps taken are tentative. The most prominent example is the Province of Santa Fe. In 1933 it established a General Hygiene Directorate (Dirección General de Higiene de la Provincia) that, by the early 1940s, had developed into a full Ministry. Mendoza instituted a General Directorate of Health and Social Assistance (Dirección General de Salubridad y Asistencia Pública). This became a Ministry of Social Assistance in 1939. Mendoza stands out from the other provinces for spending on health and welfare in the 1930s. This is principally due to its investment in public hospitals, and the social reforms instituted in the 1920s.

Provincial governments were also not very active in the provision of potable water and sanitation services. Generally, water and sanitation were left to the federal government's National Sanitation Works (Obras Sanitarias de la Nación) or to municipal governments. Only the provinces of Buenos Aires and Entre Ríos had some involvement in potable water supply. Most people in the provinces, even in urban areas, lacked a potable water supply in 1941. Santa Fe had the largest proportion of urban population supplied with water (36 percent) and Corrientes the lowest (12 percent) (Ministerio de Obras Sanitarios de la Nación 1942: n.p.). 


\section{Labour}

Labour legislation in Argentina generally was fairly rudimentary in the period under consideration. The Federal Government established a National Department of Labour in 1907/1912, and the provinces followed suit with similar organizations. Tucumán was the first in 1913, and Entre Ríos the last in 1934. Amongst the functions of these departments were the compilation of statistics, the preparation of labour legislation, the supervision and inspection of work places, the placement of labour, the investigation of industrial accidents, the mediation of strikes, and the maintenance of specialised libraries. In fact, these departments were poorly financed and staffed and did not function well.

Federal labour legislation applied to the provinces when acts were incorporated into the civil code. Thus the 1913 law of compensation for industrial accidents and industrial diseases and the 1919 law establishing the eight hour day (48 hours per week) effectively applied in the provinces as well as in the Federal Capital and the National Territories. Mendoza, Tucumán and Santa Fe had legislated the eight hour day prior to the federal act (Pichetto 1942: 392, 297).

Mendoza did establish a minimum wage for workers, including rural workers, in 1918. The law was poorly implemented, and the government itself was lax in paying its teachers and, moreover, paid its employees in Treasury Letters. These depreciated in value over time. The law was declared unconstitutional in 1929 by the National Supreme Court in the light of the Federal Government's establishment of a minimum wage system in 1921 (Rodríguez 1979: 68-77).

Provincial governments did little to solve the unemployment problem in the 1930s, although, to some extent, increased expenditure on road works slightly eased the problem. The Province of Córdoba was exceptional in that it secured a domestic loan of mn\$5 million to fund public works, including the construction of urban and rural schools, public baths, homes for neglected and abandoned children, medical dispensaries, and a school of arts and crafts, to create employment opportunities (Siewers 1935: 793-94).

Over the fifty years, provincial governments did not act decisively with regard to 
organizing or protecting workers in industry, commerce, or agriculture. Generally they followed the federal lead and even when they were ahead of that level of government, their legislation was poorly funded and executed. The major, if partial, exception to this generalisation is the Manuel Fresco government of the Province of Buenos Aires (19361940). Fresco used the Provincial Department of Labour to oversee agreements between workers and employers.

\section{Housing}

Provincial and municipal governments spent very little on public housing despite the obvious lack of adequate housing. In country areas, the typical dwelling was the rancho, a one room hut of mud walls and straw roof, while in the major cities there were large rented buildings housing multiple families (conventillos) and other overcrowded residences. Farm renters (arrendatarios) lived in makeshift homes as they generally held only three year leases on the lands they farmed and were required to move on afterwards by the large landowners. On the estates, single workers frequently lived in bunk houses, and families in ranchos. In the 1930s the housing problem appeared more acute as rural dwellers moved to the towns and created slum suburbs (villas miserias). Investigators of housing in Bahía Blanca in 1936 described the suburbs there as a profusion of ranchos made of adobe, wood and metal sheeting, and huts constructed from waste materials including boxes, tin sheets and wood off-cuts with roofs secured by heavy stones (Muzio, Pronsato, \& Casanova 1941: 91-134). A 1943 census of families in Argentine cities, conducted by the National Education Council (Consejo Nacional de Educación) (1944: 1-17), revealed that 20.7 percent of surveyed families with children had four or more persons sleeping in the same room. Overcrowding was most severe in Tucumán where 34.7 percent of families had more than four persons per room, and 18 percent of dwellings contained more than four families. But other cities with major housing problems included Santa Fe (25 percent of families with four or more sleeping per room), Avellaneda (23 percent), Rosario (22 percent), Mendoza (21 percent), Buenos Aires (19 percent), San Martín (17 percent), Bahía Blanca (14 percent), and Lomas de Zamora (10 percent).

From early in the twentieth century, provincial governments recognised the housing problem though they tended to see it as such because overcrowding resulted, in their eyes, in promiscuity and depravity, which threatened the basic unit of society, namely 
the family. Córdoba was the first province to take an active role in the provision of housing to the less well off. In 1907 it authorised the Provincial Bank to provide funds for the construction of workers’ houses. 29 had been sold by 1911 (Contaduría General de la Provincia de Córdoba 1912: 51). This initiative petered out. In 1920 the province established the Popular Savings Fund (Caja Popular de Ahorros - CPA), the statutes of which permitted excess funds to be directed towards the building of schools and workers' houses (Roca 1924: 15). By 1940, the CPA had funded 44 houses, and another 29 were under construction (Sabattini 1940: 35). In 1936, the Provincial Retirement and Pensions Fund (Caja Provincial de Jubilaciones y Pensiones) was authorised to lend 15 percent of its funds as loans to build or acquire houses for the superannuated and for provincial employees with more than ten years service. However, by 1942, only five houses had been completed, with another five under construction (del Castillo 1942: 3839).

The Province of Buenos Aires modified the statutes of its Popular Savings Fund in 1925 to permit the granting of mortgage loans to state employees, and in 1936 established a Workers' Housing Institute (Instituto de la Vivienda Obrera) to provide housing for less well off workers. Neither initiative flourished.

The Provinces of Santa Fe and Mendoza began to take an interest in housing in the late 1930s. The former, in 1938, founded a Provincial Popular Housing Commission (Comisión Provincial de la Vivienda Popular) to sell Popular Housing Bonds to a value of mn\$10 million (Ministerio de Hacienda y Obras Públicas de la Provincia de Santa Fe 1939: 163-165). This law was not put into effect. The Province of Mendoza, on the other hand, did actively engage in the construction of housing. Its 1936 law to establish a Provincial Cheap Housing Commission (Comisión Provincial de Casas Económicas) was activated in 1939, and by 1945 the province had built between 240 and 576 housing units (Contaduría General de la Provincia de Córdoba 1941: 16; Argonz 1945: 102).

Some municipal governments also sought to relieve the housing crisis. In 1926, the Municipality of Rosario created an autonomous body, the Worker's House (Vivienda del Trabajador), which had acquired some 599 modest homes by 1936. The Municipality of Santa Fe, at the same time, established a home owners scheme to grant loans to municipal workers and employees, acquired a number of houses which it 
subsequently sold, and gave tax incentives to private companies to build homes for those of modest means. The Municipality of Paraná, in 1928, also facilitated workers’ acquisition of houses. Some 82 families had benefited by 1936. The Municipality of Córdoba also acquired some modest houses for workers (Niklison 1936: 36-57).

Provincial and municipal governments did not set a high priority on the provision of housing. For the most part, they seem to have assumed that it lay outside the purview of the state. In large part this was probably due to the prevailing form of liberalism they espoused. When they did take action it was generally for the benefit of state employees and workers and it usually took the form of freeing up the savings of the workers to enable them to obtain mortgage loans. Financial considerations also played some part. In 1941, for instance, the Accountant of the Province of Córdoba, Dr Javier Lopez Zavakta, argued that the province should not follow the lead of Mendoza because the latter's Provincial Cheap Housing Commission had found that the rents it could charge on the houses it constructed were not sufficient to cover the costs of the debt it had incurred (Contaduría General de la Provincia de Córdoba 1941: 16). It is true, however, that by the late 1930s there was a growing acknowledgment that the state had to do something about the housing crisis. Even the Province of Tucumán, by late 1943, was enacting legislation to provide workers’ houses.

\section{Conclusion: Ideology, Political Will, Limited Resources and Exclusion}

The structure of provincial expenditure changes little from 1890 to 1940. Law and Order, and Education, remain the most important activities of government, although Public Works did increase significantly. On the other hand, some provincial governments did move beyond this frame into such areas as housing and health, and give some attention to labour legislation.

The pattern of activities is clearly predicated on economic liberalism. The provinces largely restricted themselves to those areas which liberalism designates as belonging to the state, namely security, education, and the construction of infrastructure to encourage production. For the Argentine provinces, this restriction of state activities was also determined by their revenues which did not permit even the core state functions to be executed as well as they might have been. The question of revenue generation lies outside the scope of this paper. Suffice to say that raising more taxes requires political 
will. That will was largely lacking. This is not surprising because the legislators generally represented the classes who possessed property and therefore held the wealth and income that could be taxed.

An overview of the annual reports (Mensajes) of the governors of the provinces reveals that the mindset of these was overwhelmingly liberal. There were exceptions such as the governors of Mendoza in the 1920s. And in the 1930s the Argentine elites did become increasingly concerned about the social consequences of Argentine development. They perceived that the birth rate was falling, that conscripts were frequently unhealthy, and that housing conditions for many were atrocious. Their response, however, was tentative and vacillating. The conservative governor of Mendoza in 1941, Adolfo A. Vicchi, is a good example of this. He recognised the need for laissez faire to be abandoned and for the state to be more interventionist, but could not transcend the oligarchic belief that the state should be controlled by an elite which would take a tutoring role with regard to labour (Vicchi 1941: 13). To some extent the failure of the liberal elite to seriously address the issues of social incorporation stemmed from the lack of a viable political opposition, and the weakness of organised labour. This weakness, however, was due, in large part, to the strength of the repressive forces of the state, themselves amply funded by the liberal oriented governments.

In the 1940s, with the advent of Peronism, there was a fundamental shift in ideology. Under the banner of Social Justice, the national and the provincial states became much more interventionist with regard to social policies and there were significant advances in the provision of social welfare, health facilities and housing. The mass of Argentine citizens was included in the political, social and economic development of the nation. This presented a major challenge to liberalism. It was not until the 1990s that it was able to re-establish its hegemony, and then only for a short time. Once again, its limitations became apparent as the numbers of the impoverished and the excluded increased, leading to the political, economic and social turmoil of 2001/2. 


\section{Reference List}

Adelman, J. 1992, 'Socialism and Democracy in the Age of the Second International,' The Hispanic American Historical Review, vol. 72, no. 2, 211-38.

Alonso, P. 1993, 'Politics and Elections in Buenos Aires, 1980-1998: The Performance of the Radical Party,' Journal of Latin American Studies, vol. 25, no. 3, 465-87.

Anonymous, 1947 Historia de la Policía, Entre Ríos.

Anuario de Estadístico de la Provincia de Tucumán Año de 1935. 1938, Tucumán.

Argonz, J. 1945, Justicia Social. El Ateneo, Buenos Aires.

Benencia, R. 2007, ‘La inmigración limitrofe,’ in Población y bienestar en la Argentina del primero al segundo centenario, comp. S. Torrado, edhasa, Buenos Aires, vol. 1, 571-600.

Canton, D. \& Jorrat, J.R. 1999, 'Buenos Aires en tiempos del voto venal: elecciones y partidos entre 1904 y 1910,' Desarrollo Económico, vol. 39, no. 155, 433-57.

Consejo Nacional de Educación (República Argentina) 1929, Educación Común en la Capital, Provincias y Territorios Nacionales. CNE, Buenos Aires.

Consejo Nacional de Educación (República Argentina) 1944, El Problema de la Vivienda Popular a través de los resultados del Censo Escolar de la Nación. CNE, Buenos Aires.

Contaduría General de la Provincia de Córdoba 1912, Balance General y Estados Demonstrativos de Cuentas correspondiente al ejercicio administrativo de 1911, Córdoba.

Contaduría General de la Provincia de Córdoba 1941, Memoria ejercicio 1941, Córdoba.

Contaduría General de la Provincia de Corrientes 1938, Memoria 1937, Corrientes.

Contaduría General de la Provincia de Santa Fe 1936, Balance y Rendición de Cuentas, Ejercicio 1935 , Santa Fe.

del Castillo, S. Gobernador 1942, Mensaje Año 1942, Córdoba.

Devoto, F.J. 2007, 'La inmigración de ultramar' in Población y bienestar en la Argentina del primero al segundo centenario, comp. S. Torrado, edhasa, Buenos Aires, vol. 1, 531-48.

Dirección General de Estadística 1896, Anuario 1895, Buenos Aires.

Dirección General de Estadística 1911, Anuario 1910, Buenos Aires.

Gobierno de Mendoza, Ministerio de Economía, Instituto de Investigaciones Económicas y Tecnologías 1954, Anuario - Síntesis Estadístico y Geográfico-Económico, Mendoza.

Horowitz, J. 1999, 'Bosses and Clients: Municipal Employment in the Buenos Aires of the Radicals, 1916-30,' Journal of Latin American Studies, vol. 31, no. 3, 617-44.

Johnson, L.L. \& Wolfson, L. 1989, 'Cambio en las pautas de arrestos policiales en tres ciudades argentinas: Buenos Aires, Santa Fe y Tucumán, 1900-1930,’ Desarrollo Económico, vol. 29, no. 113, 87-112.

Korzeniewicz, R.P. 1993, 'The Labor Politics of Radicalism: The Santa Fe Crisis of 1928,' The Hispanic American Historical Review, vol. 73, no. 1, 1-32.

Loza, E.S. Gobernador 1917, Mensaje 1917, Córdoba.

Mallimaci, F. 2007, 'Los derechos humanos y la ciudadanía como matriz de análisis social' in Población y bienestar en la Argentina del primero al segundo centenario, comp. S. Torrado, edhasa, Buenos Aires, vol. 1, 97-127.

Ministerio de Gobierno de la Provincia de Buenos Aires 1944, Dirección de Identificación Civil y Estadística General, VIII Anuario Estadístico, La Plata.

Ministerio de Gobierno y Obras Públicas de la Provincia de Entre Ríos 1932, Memoria 1932, anexo.

Ministerio de Hacienda de la Provincia de Córdoba 1936, Balance, informes y demas antecedentes relativas a la situación financiera de la Provincia desde el año 1930 al 17 de mayo de 1936, Córdoba.

Ministerio de Hacienda y Obras Públicas de la Provincia de Santa Fe 1939, Memoria. Período 10 de abril de 1938 al 10 de abril 1939, Santa Fe.

Muzio, N.P. \& Pronsato, D. \& Casanova N.A. 1941, 'La vivienda en Bahía Blanca,' La Habitación Popular, vol. 7, no. 26, 91-134.

Negretto, G.L. \& Aguilar-Rivera, J.A. 2000, 'Rethinking the Legacy of the Liberal State in Latin America: The Cases of Argentina (1853-1916) and Mexico (1857-1910),' Journal of Latin American Studies, vol. 32, no. 2, 361-97.

Niklison, C.A. 1936, 'La lucha en favor de la vivienda popular,' Acción Museo, vol. 1, 36-57.

Obras Sanitarios de la Nación 1942, El problema del agua potable en el interior del pais, Buenos Aires.

Pichetto, J.R. 1942, 'The Present State of Social Legislation in the Argentine Republic,' International Labour Review, vol. 46, no. 4, 383-419.

Posada-Carbó, E. 2000, `Electoral Juggling: A Comparative History of the Corruption of Suffrage in Latin America, 1830-1930,’ Journal of Latin American Studies, vol. 32, no. 3, 611-44. 
Rapoport, M. 2006, Historia económica, política y social de la Argentina. Ariel, Buenos Aires. Recalde, H. 1985, La Iglesia y la cuestión social (1874-1910). CEAL, Buenos Aires.

Roca, J.A. Gobernador 1924, Mensaje Año 1924, Córdoba.

Rodríguez, C. 1979, Lencinas y Cantari. El populismo cuyano en tiempos de Irigoyen. Editorial de Belgrano, Buenos Aires.

Ross, P. 1988, 'Policy Formation and Implementation of Social Welfare in Peronist Argentina 19431955,' Unpubl. PhD Thesis, UNSW.

Sabato, H. 2001, 'On Political Citizenship in Nineteenth-Century Latin America,' The American Historical Review, vol. 106, no. 4, 1290-1315.

Sabattini, A.S. Gobernador 1940, Mensaje Año 1940, Córdoba.

Siewers E. 1935, 'Unemployment in Argentina,’ International Labour Review, vol. 31, no. 6, 786-810.

Solberg, C. 1971, 'Rural Unrest and Agrarian Policy in Argentina, 1912-1930,' Journal of Interamerican Studies and World Affairs, vol. 13, no. 1, 18-52.

Solberg, C. 1973, 'The Tariff and Politics in Argentina 1916-1930,' The Hispanic American Historical Review, vol. 53, no. 2, 260-84.

Sonzogni C.M. 1983, Evolución de la actividad tabacalera en Corrientes y en Misiones (1870-1940), Cuadernos de Geohistoria Regional, Instituto de Investigaciones Geohistóricas, Corrientes.

Taylor C. 1948, Rural Life in Argentina, Louisiana State University Press, Baton Rouge.

Tedesco, J.C., \& Cardini, C. 2007, 'Educación y sociedad: proyectos educativos y perspectives futuras,' in Población y bienestar en la Argentina del primero al segundo centenario, comp. S. Torrado, edhasa, Buenos Aires, Vol. II, 439-68.

Zimmermann, E.A. 1992 'Racial Ideas and Social Reform: Argentina, 1890-1916,' The Hispanic American Historical Review, vol. 72, no. 1, 23-46.

Vicchi, A.A., Gobernador 1941, Mensaje 1941, Mendoza. 